\title{
THE (MIS)USES OF LIFE HISTORIES. THE LINGUISTIC TURN, LIFE HISTORIES AND (WOMEN'S) LIFE STORIES
}

\section{Claudia de Lima Costa}

\section{Universidade Federal de Santa Catarina - Brasil}

\begin{abstract}
This paper retraces the debates on life-histories before and after the linguistic turn in the social sciences, and, more specifically, in the anthropological tradition. It stresses how poststructuralist feminist methodological, theoretical, and political appropriations of personal narratives represent a significant textual intervention in the gendered social-cultural scripts of women's lives.
\end{abstract}

Keywords: feminist theories, life history, subjectivity, women’s life stories.

Resumo: Este artigo analisa os debates sobre histórias de vida que antecederam e sucederam as discussões sobre a virada linguística nas ciências sociais, principalmente na tradição antropológica. $O$ artigo argumenta que o feminismo pós-estruturalista, ao reapropriar-se teórica, metodológica e politicamente das histórias de vida, representou importante intervenção nos "textos" sociais e culturais disponíveis às mulheres na construção de seus relatos de vida e de suas subjetividades.

Palavras-chave: história de vida, narrativa de mulheres, subjetividade, teorias feministas.

\section{Personal narratives and the positivist turn in the social sciences}

In a comprehensive review of life history research in anthropology, Watson and Watson-Franke (1985, p. 1-2) observe that, although personal narratives have been used in scientific research for more than seventy years now, they have until recently occupied a marginal position vis-à-vis other methods such as structured observation, interviewing, and related procedures for experimentation and hypothesis testing. During the 1940s, the rise of quantification 
and rigorous empirical measurement in the study of society pushed life accounts further to the periphery - to the realm of the mundane, the quotidian - hence contributing to their radical invisibility after a brief period of prestige, under the auspices of sociologists at the University of Chicago. Though some social scientists continued using testimony and personal narrative as germane research instruments (e.g., John Dollar and Franz Boas), they never ceased to be regarded as insufficient, partial, if not unwieldy because excessively biased by subjective circumstances (Queiroz, 1988).

Individuality and subjectivity - despite being considered potentially important attributes for shedding light on emotions hidden behind statistical data in the study of human behavior within larger contexts - were deemed to have a limited reach in terms of establishing generalization and comparison. This explains why such accounts, when published, seldom stood alone in the final text, but were usually followed by the author(s)' copious comments upon the Ufe experience being portrayed. Crapanzano (1984, p. 954), in a review of life-histories, cleverly remarked that such commentary, attempting to mediate the tension between intimate field experience and analysis and presentation, often oscillated between being "saccharine in its sentimentality and overambitious in its justification."

Even anthropologists, for whom reports of experience by native informants lie at the heart of ethnographic fieldwork, did not know what to do with them. In some cases such accounts would be allowed to 'speak for themselves', while the authors underscored either the compelling nature of their illustrations or the literary qualities of their presentations. ${ }^{1}$ As Watson and Watson-Franke (1985, p. 4) put it, Anthropologists, from the beginning of the discipline, collected personal histories from the individuals in the cultures they studied. Eliciting accounts of individual experiences to obtain information about general practices was in the very nature of ethnographic fieldwork. Individual accounts were checked against other individual accounts, synthesized, and supplemented by the fieldworker's own observations to form the basis of the ethnographic monograph. But, also from the beginning, the personal accounts themselves were lost in the monograph - summarized and dissected into the conventional cultural categories - often with no reference to the actual persons who contributed information.

When the detailed life history of a single person found its way into the published monograph, the individual stood as representative of similar

1 See, for example, Oscar Lewis (1961). 
individuals in his/her social milieu. Hence culture was apprehended through a "typical” individual's experience, the criteria for typicality remaining unclear in most cases (Watson; Watson-Franke, 1985).

During the 1930s, life history documents were also used with some ubiquity in the emergent field of psychocultural studies. The analysis of individual life trajectories - "the ultimate reality in the realm of culture" (DuBois, 1937, p. 285-286) - would elucidate the ways culture was transmitted (for instance, through practices such as child rearing and sex-role learning), as well as how it shaped individuals' personalities. ${ }^{2}$ However, life history methodology was already receiving several criticisms from positivist-oriented researchers, who began questioning the scientific worth of such studies. As mentioned above, the 1940s witnessed the steadfast rise of empirical research, along with its standards of sampling, validity, reliability, and objectivity, foreshadowing the historical collapse of life history studies. At best, this method remained an adjunct to the survey and statistical analysis. As Becker stated in 1966 (in Denzin, 1970, p. 255), [s]ociologists became more concerned with the development of abstract theory and correspondingly less interested in full and detailed accounts of specific organizations and communities. They wanted data formulated in the abstract categories of their own theories rather than in the categories that seemed most relevant to the people they studied. The life history was suited to the latter task, but of little immediately apparent use in the former.

Personal narrative was not only considered "illegitimate" within the social sciences after the positivist turn, but its devaluation extended to the humanities as well. Even in the hierarchy of discourse research, as Langellier (1989) tells us, personal narrative tended to be positioned at the lower end. According to her, [t]his hierarchy of discourse privileges other discourses over narrative (e.g., fact over anecdote in the social and human sciences; poetry over fiction in literature; and poetic over ordinary language), other narrative over personal narrative (the novel over the personal narrative; myth as the measure of narrative, followed by legends, folktales, and other oral traditions), and some personal narratives over others, especially those of dominant groups over subordinate groups (Langellier, 1989, p. 272).

Life accounts, by valuing "the mundane, everyday, private, informal" world of ordinary people (Langellier, 1989, p. 272), were more often than not situated at the margins of the disciplines, constituting a "blurred genre"

2 See Watson and Watson-Franke (1985, p. 6-10) for a review of some of these works. 
or a "boundary phenomenon" constantly challenging conventional distinctions between literary and social discourse, fact and fiction, text and context (Langellier, 1989, p. 243). Nonetheless, during the 1960s, paradigm transformations taking place within the social scientific community would soon alter the traditional divisions amongst the disciplines which, in turn, encouraged new theoretical and methodological inroads. These changes were ensued by a revaluing and -most importantly - revisioning of personal narratives in methods of analysis. In what follows I will plot these changes by also introducing feminist concerns regarding women's life stories.

\section{The refiguring of social thought}

The social and political unrest and protest that erupted in the 1960s left damaging cracks in the walls of the scientific community both in the American and European continents, undermining the project of a social science modeled on the natural sciences (Rabinow; Sullivan, 1979, p. 1-5). In the aftermath of World War II, faced with the horrors of Nazism and Fascism, the belief in the liberating use of reason turned into widespread skepticism. Those associated with the hermeneutic and critical theory tradition accused scientific knowledge of being "a disguised form of ideology that lent support to the status quo” (Bernstein, 1978, p. xi). As technology came to dominate every aspect of social existence, and as public policies fell to the domain of technocratic elite, the belief in scientism no longer remained unchallenged. ${ }^{3}$ Critics from many academic camps denounced the role the positivist sciences had played and still play in exerting and legitimizing forms of socio-technical control over

\footnotetext{
Scientism is the doctrine that a positivist social science, with its firm empirical foundation and its objective scientific knowledge will provide a better basis for the attainment of social equality through careful analyses of, and prescription of remedies for, widespread social problems and inequalities. As Bernstein (1978, p. 106) forcefully puts it, "[t]he issue is not whether it is possible to employ empirical and quantitative techniques [in studying social and political reality], but rather how to interpret the results. There has been an overwhelming tendency in mainstream social science toward reification, toward mistaking historically conditioned social and political patterns for an unchangeable brute reality which is simply 'out there' to be confronted.... The most serious defect in this endeavor is not simply unwarranted generalizations, but the hidden ideological bases. There has been a lack of critical self-consciousness among mainstream social scientists that the admonition to be 'realistic,' to study the way things are, is not so much a scientific imperative as a dubious moral imperative that has pernicious consequences in limiting human imagination and political and social possibilities. Scientism in social and political studies has become a powerful albeit disguised ideology."
}

Horizontes Antropológicos, Porto Alegre, ano 5, n. 12, p. 133-151, dez. 1999 
human beings in the service of domination. Important questions began to be raised concerning the relationship between social theory, its epistemological, methodological, and political aspects, and social practice. ${ }^{4}$

Emerging out of this scenario of tumbling orthodoxies - in the backdrop of which lie more fundamental issues (such as the nature of human beings, of knowledge, and the relationship between knowledge and power) - were alternative approaches to a naturalistic understanding of social formations (Bernstein, 1978, p. 51-54). Thus, for instance, in the intellectual landscape we have, first, a new understanding of the complexity of language, voiced by those theorists associated with the linguistic turn in analytic philosophy (Wittgenstein and Austin), and, second, the rehabilitation of phenomenology, hermeneutics and its emphasis on interpretive understanding, rather than prediction and control. Attention is given to the significance of communicative interaction, that is, to the dynamic dialogue between theorist and subjects in order to make sense of a common world that is taken to be grounded upon intersubjective meanings. A third alternative to positivist social theories is best represented by the writings of those associated with the Frankfurt School of Critical Theory. Critical theorists, among them Habermas, were deeply skeptical about the earlier attempts by hermeneutic theories to understand society, because of the emphasis placed on the self-understanding of social agents. Critical theorists claimed that hermeneutics did not account for ideological influences or unconscious motives, which distorted the very self-understanding of the agents it was trying to interpret. An important step critical theory should take was to make the subjects it studied aware of their own subjection to political and economic structures through a critique of their own self-understandings. Only then would it make sense to talk about human emancipation, the aim of critical theory.

To summarize my discussion, these debates and critiques contributed in radical ways to the refiguring of social thought in that they brought about major changes in social science's conceptions of "the object of analysis, the language of analysis, and the position of the analyst” (Geertz in Rosaldo, 1989, p. 37). Moreover, it is worth noticing in relation to these new approaches that they reflect what became known as "the linguistic turn" in social theory.

4 For earlier feminist critiques of epistemology, see the groundbreaking work of Ruth Bleier (1984), Evelyn Fox-Keller (1985), and Sandra Harding 1986). 


\section{The linguistic turn}

The phrase "linguistic turn,” although first coined by Gustav Bergmann, a logical empiricist and member of the Vienna Circle, gained popularity after the publication, in 1967, of Richard Rorty's The Linguistic Turn: Recent Essays in Philosophical Method, which signaled an already ongoing concern with language among various intellectuals (Dallmayr, 1984).

It would be beyond the scope of this essay to chart the factors and debates that led up to the paradigm changes in the social sciences along with the plethora of diverse and incompatible perspectives with regard to conceptions of language. ${ }^{5}$ It suffices to say that a focus on language in use, on linguistic practices (vis-à-vis the study of language structures and formal properties) was the most significant aftermath of the linguistic turn, which lead to new theoretical inroads, including the theory of communicative action and critique of ideology (Habermas), the study of 'language games' (Lyotard), the politics of language in use (Foucault), a hermeneutics of suspicion (Ricoeur), a philosophical hermeneutics (Gadamer), or the project of deconstructing the metaphysical foundations of Western epistemology (Derrida) (Baynes; Bohman; McCarthy, 1987). Along with such developments, the boundaries between the various disciplines became blurred. Theorists daringly ventured across the rigid disciplinary fault lines that had so far unyieldingly separated the social sciences from the humanities. In assessing the field of anthropology - in an inexcusable gender-biased way, I would remind - Clifford (1986a, p. 3) argues that we are presently witnessing in some anthropological writings a combination of perspectives and traditions that include historical ethnography, cultural poetics, cultural criticism, the analysis of implicit knowledges and everyday practices, the critique of hegemonic structures of feeling (to cite a few) which comprise "all those studies that focus on meaning systems, disputed traditions, or cultural artifacts." 6

In the next section I want to gauge the reverberations that the changes discussed above surrounding questions of language and representation prompted in life histories studies.

\footnotetext{
See Dallmayr (1984) for a comprehensive account of such epistemological concerns with language.

6 In my paper "Etnografia, representação e prática política: os dilemas do feminismo na escrita da cultura” (De Lima Costa, in press), I survey feminists’ responses to Clifford’s dismissal of feminist writers and theorists from the 'new ethnography' movement in anthropology.
} 


\section{The linguistic turn and beyond: life history studies re-visited}

With the wane of the empiricist dogma in the 1960s, and in light of language's newly acquired importance among social scientists, interpretation and understanding - not explanation - became guiding concepts to provide us with some access to the social world. If, in the years that preceded the rise of hermeneutics, researchers were at a loss concerning what to do exactly with life history accounts, in the 1960s they began to be viewed as rich sources for the study of the subjective experience of individuals and their particular constructions of the social and cultural worlds surrounding them. In other words, interpretive research would focus "on those life experiences that... shape the meanings persons give to themselves and their life projects" (Denzin, 1997, p. 15). For many researchers, personal accounts offered an interpretive framework through which the meaning of human experience [could be] revealed in a way that [would give] priority to individual explanations of actions rather than to methods that filter and sort responses into predetermined conceptual categories (Jones, 1983, p. 147).

Life histories attained a new legitimacy in their return to the academic scene by way of studies conducted within the theoretical framework of symbolic interactionism or, more recently, under the rubric of interpretive interactionism (Denzin, 1997). ${ }^{7}$ Scholars were interested in mapping the interconnections between the micro-context (e.g., the individual's accounts of their experiences) and the macro-social processes and dynamics in ways that would avoid the pitfalls of a reductive functionalism, structuralism, or orthodox Marxism. It is by looking at the lives of ordinary people that features of abstract processes and structures can be captured. Analytic categories such as "base”, "superstructure”, “division of labor”, “bureaucracy”, “ego-function”, “functional prerequisites", "distorted communication", "or the latent consequences of purposive action”, (Denzin, 1997, p. 25) were to be replaced by 'lived reality' (MerleauPonty's "prose of the world") so as to avoid that the latter be divorced from the scientist's analysis. However, as Denzin (1997, p. 25) admonishes, [t]his world does not stand still, nor will it conform to the scientist's logical schemes of

\footnotetext{
For Denzin (1997, p. 10, 12), since in social life there is only interpretation, interpretive interactionism "speaks to the interrelationship between private lives and public responses to personal troubles." Thus, "the individual's perspective is definitionally critical for establishing the 'what' and... the 'how' of problematic social experience. The task is to produce 'richly detailed' descriptions and accounts of such experiences.”
} 
analysis. It contains its own dialectic and its own internal logic. This meaning can only be discovered by the observer's participation in the world. The world does not stand independent of perception or observer organization. In these respects researchers find that their own worlds of experience are the proper subject matter of inquiry. Unlike the positivists, who separate themselves from the worlds they study, the interpretivists participate in the social world so as to understand and express more effectively its emergent properties and features.

Besides their neglect of analysis and interpretation, also missing from life histories studies had been reflections on the influence of the investigator and the field situation in structuring the outcome of personal accounts, a preoccupation brought into the research context in the 1970s by the interpretivists, especially those influenced by Foucault's trenchant critique of the modern episteme.

Crapanzano (1984, p. 953), for instance, remarked with ironic curiosity that just as Foucault was heralding a new "man-less science of man" in some quarters - one in which language had de-centered man (sic) - in other quarters we were witnessing a sudden resurgence of interest in life histories. As discussed earlier in this essay, Crapanzano was criticizing certain interpretive practices that viewed a 'typical' individual's life history as "portraying" or "illustrating" some aspect of his or her culture. He warned that underneath the idea of 'typicality' lurked a peculiarly homogeneous view of culture, society and the individual that itself often responded to an imposition by the researcher on the informant's words/ worlds (e.g., 'life history' itself may be a construct alien for the subject; it is the interviewer who selects the informants, who asks the questions and contributes to the final shaping of the testimony). Among other cautionary observations, Crapanzano (1984, p. 955-956) argued that the life history is the result of a complex self-constituting negotiation. It is the product (at least, from the subject's point of view) of an arbitrary and peculiar demand from another subject - the anthropologist. (At some level, the anthropologist's demand is always a response to the informant.) The interplay [...] of demand and desire governs much of the content of the life history, and this interplay, the dynamics of the interview, must be taken into consideration in any evaluation of the material collected.

The turn towards the interpretive approach allowed not only for critical re-appraisals of so-called scientific methods in the study of culture, meaning systems and life forms, but also demanded that the researcher turn the gaze upon him/herself as well. In the same vein as Crapanzano, Burgos (1989) calls for a careful exploration of the extent to which the discourse of the informant is a response to the wishes and expectations of the person conducting 
the interview. According to her, this problem characterizes the fundamental ambiguity that one faces in the understanding of life story, especially when it is a question not of a "spontaneous" autobiography but of one that has been elicited by a researcher, produced by a process of questioning which, even if the questions are as open as possible, does not necessarily follow the immediate interests of the narrator. The importance of whether it is written or oral is also a complex problem that needs fuller consideration (Burgos, 1989, p. 29).

Moreover, in the blurring of boundaries between the disciplines mentioned above, other aspects of personal documents came under close scrutiny so that adequate interpretation could be possible: its textual nature, its narrative form, and the fact that the life history - besides being the product of a specific encounter "interdigitates with other story forms in the subject's culture [...] [which includes notions of] authorship, rhetoric, style, and narrative techniques" (Crapanzano, 1984, p. 957). ${ }^{8}$ Rosaldo (1980, p. 21) aptly captured such multiple mediations and interventions present in the life historical text by stating that "[d]oing oral history involves telling stories about stories people tell about themselves." What remains necessary at this point is to probe the methodological implications for seeing life histories as textual narratives. It is to these considerations that I now turn.

\section{From life history to life story}

To envisage life histories as texts is useful in two significant respects. First, texts necessarily call our attention to the context of their creation, that is, to the power relations, institutional constraints, resistances and contestations that are inscribed in them. Secondly, insofar as texts are always mediated by a language or meaning systems, they are conceived as discursive (or signifying) practices that do not represent but construct their object of knowledge. Seeing life histories as texts, then, makes the politics of knowledge production and dissemination more visible and signals (as previously discussed) an important, and characteristically postmodern, shift from a representational to a narrative paradigm in epistemology.

Inasmuch as life histories are the product of a negotiation in the ethnographic encounter, one may say that they are constituted through a specific

8 Among the narrative techniques listed by Crapanzano (1984) are figurative language, imagery, allegory, double entendre, humor, irony, beginnings and endings, conventional silences, suspense, and denouement. 
transformation - the conversion of the oral material into the recorded tape transposed, in turn, into the written product. Consequently, first, they are not just data, but texts, narratives with their own logic; second, the other is always speaking through the world of the text which, in turn, carries within it all the “ontological and epistemological burdens" of a text (Crapanzano, 1984, p. 957).

To provide a definition of what qualifies as a "text" has become indeed difficult nowadays, as there is a whole array of phenomena claiming for themselves a textual status - varying from a wine bottle label to a painting, to a television commercial, to a city map - as there are paradigms for reading these "texts." In my ensuing discussion I will be referring to a specific text: the life story that is the result of the transcription (coupled, more often than not, by the editing) of an orally collected personal narrative.

According to Ricoeur (1979, p. 78), when living speech (a fleeting event) is fixed into writing, it undergoes significant changes. First, what writing fixes is not the event of speaking, but the "said" of speaking, the meaning of the speech event. Second, whereas in spoken discourse the subjective intention of the speaking subject and the meaning of discourse overlap with each other, in written discourse the two cease to coincide. As he warns us, it is not that the speaker entirely disappears from the text, but "the text's career escapes the finite horizon lived by its author. [...] What the text says now matters more than what the author meant to say." As a consequence of being in public (rather than in the limited sphere of the dialogical situation), written discourse (e.g., the life story) is intersubjective and open to interpretation. This is to say, more radically, that the life historical text is not owned either by the narrator telling the story, or by his or her interlocutor recording and transcribing it. Third, since discourse refers to a world, spoken discourse, on the one hand, points to a situation common to the interlocutors, which contextualizes the dialogue and makes reference ostensible; writing, on the other hand, frees the text's reference from the limits of manifest reference. ${ }^{9}$ Finally, whereas spoken discourse is addressed to an interlocutor equally present to the discourse situation, writing is addressed to whoever knows how to read, to the audience

\footnotetext{
As Ricoeur (1979, p. 79) avers, "texts speak about the world... [and] the world is the ensemble of references opened up by the texts. Thus we speak about the "world” of Greece, not to designate any more what were the situations for those who lived them, but to designate the non-situational references which outlive the effacement of the first and which henceforth are offered as possible modes of being, as symbolic dimensions of our being-in-the-world. [...] Only writing, in freeing itself, not only from its author, but from the narrowness of the dialogical situation, reveals this destination of discourse as projecting a world.”
} 
that it creates itself. In freeing itself from the limits of the face to face situation, writing has made "[a]n unknown, invisible, reader [...] the unprivileged addressee of the discourse” (Ricoeur, 1979, p. 80).

To summarize, following Ricoeur's insights, once the personal account becomes the transcript that will result in the life historical text, its openness as dialogue, together with its evocative and performative elements, are lost: the rhythms, punctuation and silences of speech, which mark the narrator's participation in the story, are gone; the speaker's intonation, which may cause the same statement to have contradictory meanings as well as signal the way the story affects the narrator, is absent in the written document; the events in the life of the narrator often follow a chronological pattern, partly induced by the questions structuring the interview situation; the transcript is edited into the life historical text (what constantly places/displaces the narrator's voice) and, finally, given a title. Living, henceforth, becomes easily organized into a continuous narrative, and "events are embalmed in the structure of the text" along with the linguistic tropes that affect the way a life will make sense in determined acts of reading (Clifford, 1986b, p. 106). The final document, then, as with any representation, can be said to portray a culture only obliquely. ${ }^{10}$

Portelli (1981) also draws other relevant points concerning the life historical text. First, since testimonies derived from interviews are, as observed above, organized as narratives, some categories of literary theory should be brought to bear upon their interpretation, such as velocity of narration (e.g., how long a narrator dwells on the telling of an event is indicative of the subjective meaning that event holds for he/him), perspective or narrative focus (defining the position of the narrator towards the story), and the distinction between fact and fiction, story (fabula) and discourse (plot).$^{11}$ As Portelli (1981, p. 99) writes, in the folk narrative tradition of the non-hegemonic groups, the distinctions between narrative genres are perceived differently than in the written tradition of the educated classes. Since writing has absorbed most of the functions of cer-

${ }^{10}$ For a discussion of the narrativization of one's life, see also Pierre Bourdieu (1996).

11 The recognition of the narrative or poetic texture of our knowledge of the human world (enmeshed in the web of language and symbol) is very much a legacy of the interpretive approach in the social sciences. As Taylor (1985) comments, we are always in a cultural world, amidst webs of signification we ourselves have spun and which demand from us interpretations and interpretations of interpretations. Furthermore, according to Chanfrault-Duchet (1991), the facts and events of one's life, recounted following the narrative structure of the life story, take their meanings from this very structure in which they are embedded. Accordingly, she advises that "oral historians must have recourse to an interdisciplinary approach that borrows its concepts and methods initially from narratology and textual analysis” (Chanfrault-Duchet, 1991, p. 79).

Horizontes Antropológicos, Porto Alegre, ano 5, n. 12, p. 133-151, dez. 1999 
tification, official testimony and educational process, oral narration in a literate society finds it less necessary to establish a rigorous distinction between 'actual' and 'artistic' narrative, between 'events' and feelings and imagination. The perception of an account as 'true' is relevant as much to legend as to personal experience and historical memory; and as there are no oral forms specifically destined to transmit historical information, historical, "poetical” and legendary narrative often become inextricably mixed up. The result is narratives where the boundary between what takes place outside the narrator and what happens inside, between what concerns him or her and what concerns the group, becomes quite thin, and personal "truth" may coincide with collective "imagination".

The second point made by Portelli (1981, p. 99-100) concerning oral testimonies refers to the distinction - much explored in narrative studies -between story and discourse (plot). More important than the narration of the events or facts in one's life is the organization of the narrative (discourse), that is, how events are placed in a sequence in order for the narrator to tell the story, bestowing upon them meaning. This internal arrangement of materials guided, in turn, by the speaker's subjective choices, “tells us less about events as such than about their meaning [...] [they] tell us not just what people did, but what they wanted to do, what they believed they were doing, what they now think they did". Outside the narrative structure, such events stand for an unreachable reality. Furthermore, the 'enplotment' of events into a narrative continuity out of discontinuous experiences leading to a (sometimes imposed) coherent totality - a life - cannot be anything else but a temporary closure or "unstable equilibrium always threatened by the movement of time" (Burgos, 1989, p. 36). Through narration, according to Ricoeur, the aporias of reality, though not eliminated, at least cease to be paralyzing and become productive. Narrative, then, because contingent upon the structures of the world strengthens the links between life and story, instead of camouflaging or collapsing them. Despite being a specific form of narrative based on the individual subject, life stories maintain the tension between the individual and the social: "it is not the formation of the private self which is the main goal of the story, but the connection between these two poles" (Burgos, 1989, p. 31).

Finally, and most significantly, since control of the life history (gathered orally), with rare exceptions, tends to remain in the hands of the interviewer (as Crapanzano has pointed out earlier), it would be indeed naive to view oral history as revealing the subaltern's silent voice or, in other words, as "giving voice to the voiceless." Portelli (1981, p. 105) stresses that in any oral account, the 
informant "does not speak in the abstract, but speaks to the historian, and with the historian (and, inasmuch as the material is published, through the historian)," making the latter into a sort of ventriloquist. That being the case, we can say that the interviewer occupies less the role of a go-between from the narrator to the reader and more of a protagonist: on entering the story and explicitly declaring control over it, he or she must on that very account allow the sources to enter the tale with their autonomous discourse. Thus, oral history is told from a multitude of 'circumscribed points of view': the impartiality claimed by traditional historians is replaced by the partiality of the narrator (where partiality stands both for taking sides and for unfinishedness). The partiality of oral history is both political and narrative: it can never be told without taking sides, since the 'sides' exist inside the account (Portelli, 1981, p. 106).

\section{From life-story to women's life stories}

Edward Said, responding to a prevalent tendency in the literary community towards an exacerbated attention to textuality to the detriment of more socially grounded decodings of texts (what he calls "secular criticism"), in the introduction of his book The World, the Text, and the Critic (Said, 1983, p. 4), argues that [e]ven if we accept (as in the main I do) the arguments put forward by Hayden White - that there is no way to get past texts in order to apprehend "real" history directly - it is still possible to say that such a claim need not also eliminate interest in the events and the circumstances entailed by and expressed in the texts themselves. Those events and circumstances are textual too and much that goes on in texts alludes to them, affiliates itself directly to them. My position is that texts are worldly, to some degree they are events, and, even when they appear to deny it, they are nevertheless a part of the social world, human life, and of course the historical moments in which they are located and interpreted. (emphasis in the original).

In a rejoinder to Said's call for a secular criticism, Harlow (1987) uses the phrase "resistance literature" to describe a whole array of texts - such as diaries, prison letters, memoirs, testimonies, life-stories, autobiographies, and so forth - which have been outcast from the (Western) canon by the literary institution due to their lesser status. For Harlow (1986, p. 508), such examples of "minor literature" reflect a "secular critical consciousness" on the part of those groups that have historically been relegated to the margins of social and interpretive power. What seems to characterize such body of writing or, 
as Kaplan (1992, p. 119) calls it (after Derrida) “out-law genres” is, first, a marked geopolitical situation of conflict between the West and non-Western resistance movements; and, second, a generalized crisis of representation emerging out of a critique of language as a transparent medium of communication. As soon as language and its apparatuses of representation were shown to be tightly imbricated with ideology and power, oppressed and heretofore "silenced" groups began articulating oppositional discursive practices (such as the creation of alternative genres) to represent themselves, thus inaugurating new narrative paradigms. According to Harlow (1986, p. 502-503), [i]n the same way that institutions of power are subverted by the demand on the part of dispossessed groups for an access to history, power, and resources, so too are the narrative paradigms and their textual authority being transformed by the historical and literary articulation of those demands.

It is in such context that we can see "third world" women's life-stories and testimonies as being an integral part of the intellectual, ideological, political, and even armed struggle waged by oppressed people against the powers of repressive states and hegemonic groups. However, the attempt to place some of these life-stories into larger contexts (both material and textual) of relations of power is not without problems. In Western intellectual circles, for instance, there is a tendency to romanticize these voices and to conceive of the subjects of the testimonials unproblematically - as always resisting their oppression through various strategies of textual subversion. While there is undoubtedly a certain truth to the quality of textual "play" in such readings of testimonial narratives, we must be careful not to overlook, to heed Said's (1983) call, the "worldliness" of the struggles waged through and in discursive spaces.

I should stress that although testimonies and life accounts are not considered to be an exclusively female genre, as Franco (1992, p. 109-110) has pointed out, they have historically been a means by which subaltern women, who did not have access to writing or were not professional writers, were able to inscribe their voices and lives, transgressing therefore the limits of their domestic space to other counterpublic arenas of discourse. Herein lies the importance, already very much stressed by feminist critics, of linking the question of genre and gender in the study of this literary form.

In fact, to explore the ways in which the tension between gender and genre (such as testimony) plays out in making possible the construction of a sense of self for women has been of foremost importance for feminist researchers at a time when questions concerning the interpellation of the (gendered) subject 
have become paramount in cultural theory. ${ }^{12}$ Likewise, since the stories individuals recount are already inscribed in larger cultural networks or narrative models, to analyze how "the limits placed on women's lives may affect what models are available to them for telling their own life stories" (Personal Narratives Group, 1989, p. 100) has been an equally significant preoccupation of feminist scholarship vis-à-vis personal narratives. Moreover, as this research collective emphasizes, resistance, acceptance, or even adaptation of certain narrative forms is very much informed by the reality of a woman's life and her (often politically conscious) attempts to circumvent such limitations. ${ }^{13}$

A last observation about the interplay between gender and genre is in order. In the specific example of testimony, one cannot allude to the above tension without underscoring the fact that testimonies are multiply-mediated texts, thereby further problematizing the issue of power imbalance between narrator and scribe. How are feminists to avoid the appropriation of the other woman's voice, i.e., the ventriloquism mentioned earlier in my discussion?

Given the distance that separates the narrator of the testimony and its scribe, feminists have been concerned about deploying strategies that have been in part successful in overcoming some of the pointed asymmetries between them, henceforth enabling the construction of coalitions among different (feminist) subjects (including the readers of testimony). One of these strategies has been the specification of the locations that narrator, scribe, and other interlocutors occupy in the various discursive economies (as well as their complicities with such locations) so as not to collapse them.

What is instigating about the testimony, however, is that this strategy is already embedded in the genre itself in that the testimony simultaneously approximates and distances the parts involved in its production. On the one hand, it asks for complicity on our part insofar as it entails a dialogue between the narrator and ourselves (either in the role of the scribe or as its readers). In that sense, Passerini (1989) points out that, far from being in the comfortable

12 For a discussion of the interpellation of the gendered subject in cultural theory, see De Lima Costa (forthcoming).

${ }^{13}$ Crista Wolf, for instance, stands as an example of the political transgression of existing narrative forms when she blends several literary genres (biography, autobiography, fiction) to create "something new in a political system often marked by the perils of censorship and ideological rigidity” (Personal Narratives Group, 1989, p. 101). Other outstanding illustrations of such trangressions are the writings of many latina women, among whom one could cite Gloria Anzaldúa and Cherríe Moraga. See Caplan (1997) for other examples of alternative practices of inscribing the self that are informed by women's different locations in gender, sexuality, class, race, ethnicity, and so forth.

Horizontes Antropológicos, Porto Alegre, ano 5, n. 12, p. 133-151, dez. 1999 
position of mere mediator, the interlocutor/scribe of the testimony becomes one of the characters in the account, and the very telling of the story is part of the story being told. As a consequence, the testimony demands solidarity from its readers. The interlocutor becomes a second witness to the events that have shaped the narrator's Ufe (Beverley, 1992). On the other hand, the silences, secrets and reticences that invariably punctuate the narrative of one's life may inform as much as dis/inform, constituting thereby a double movement of identification and dis/identification that attempts to resist the (often-violent) ventriloquist appropriation of the subaltern's voice. ${ }^{14}$

To conclude, then, we may say that the underscoring of both the poetic and the political facets of life historical texts owes considerably to poststructuralist informed critiques of representational practices, specially the ones issuing from within feminist theory and ethnography. The importance of the testimony for feminism, in its double movement of proximity and distance, is well captured in the words of Sommer (1991, p. 69), in that the distance it creates between subject and readers "can be read as a lesson in the condition of possibility for coalition politics. It is similar to learning that respect is the condition of possibility for the kind of love that takes care not to simply appropriate its object.”

Finally, to avoid indifference to difference (e.g., to the difference the women's stories make), it is imperative that one resists the reduction of subjects to theoretical constructs too far removed from historically situated concrete beings. Hence the importance of a focus on the subject's experience of the social (captured through her life narratives), as well as an understanding of how these experiences (in all their ontological and epistemological dimensions) are produced as a response to the exigencies of the social field.

\section{References}

BAYNES, K.; BOHMAN, J.; McCARTHY, T. (Ed.). After philosophy: end or transformation? Cambridge: MIT Press, 1987.

${ }^{14}$ For an analysis of these strategies in Rigoberta Menchu, see my own study (under Salazar, 1991) and Doris Sommer (1991). For a discussion of the dialogical and democratizing force of testimonies, see George Yúdice (1996). Finally, see de Lima Costa (1997) for the twin questions of location and locution in life histories and autobiographies. 
BEVERLEY, J. The margin at the center: on testimonio. In: SMITH, S.; WATSON, J. De/Colonizing the subject: the politics of gender in women's autobiography. Minneapolis: University of Minnesota Press, 1992.

BERNSTEIN, R. J. The restructuring of social and political theory. Philadelphia: University of Pennsylvania Press, 1978.

BOURDIEU, P. A ilusão autobiográfica. In: FERREIRA, M. de M.; AMADO, J. (Ed.). Usos e abusos da historia oral. Rio de Janeiro: Editora da Fundação Getúlio Vargas, 1996. p. 183-192.

BURGOS, M. Life stories, narrativity, and the search for the self. Life Stories/ Recits de Vie, n. 5, p. 29-38, 1989.

CLIFFORD, J. Introduction. In: CLIFFORD, J.; MARCUS, G. (Ed.). Writing culture: the poetics and politics of ethnography. Berkeley: University of California Press, 1986a. p. 1-26.

CLIFFORD, J. On ethnographic allegory. In: CLIFFORD, J.; MARCUS, G. (Ed.). Writing culture: the poetics and politics of ethnography. Berkeley: University of California Press, 1986b. p. 98-121.

CHANFRAULT-DUCHET, M.-F. Narrative structures, social models, and symbolic representation in the life story. In: GLUCK, S. B.; PATAI, D. (Ed.). Women's words: the feminist practice of oral history. New York: Routledge, 1991. p. 77-92.

CRAPANZANO, V. Life-Histories. American Anthropologist, n. 86, p. 953-959, 1984.

DALLMAYR, F. Language and politics. Notre Dame: University of Notre Dame Press, 1984.

DE LIMA COSTA, C. Situando o sujeito do feminismo: o lugar da teoria, as margens e a teoria do lugar. Travessia, n. 29/30, p. 123-160, 1997.

DE LIMA COSTA, C. The subject in feminism. Revista Mexicana de Ciencias Políticas y Sociales. (forthcoming).

DE LIMA COSTA, C. Etnografia, representação e prática política: os dilemas do feminismo na escrita da cultura. (in press). 
DENZIN, N. K. The research act: a theoretical introduction to sociological methods. Chicago: Aldine Publishing Company, 1970.

DENZIN, N. K. Interpretive ethnography: ethnographic practices for the 21st century. Thousand Oaks: Sage, 1997.

DUBOIS, C. Some psychological objectives and techniques in ethnography. Journal of Social Psychology, n. 8, p. 285-301, 1937.

FRANCO, J. "Si me permiten hablar": la lucha por el poder interpretativo. Revista de Crítica Literaria Latinoamericana, n. 36, p. 109-116, 1992.

HARLOW, B. From the women's prison: Third World women's narratives of prison. Feminist Studies, n. 12, p. 501-524, 1986.

HARLOW, B. Resistance literature. New York: Methuen, 1987.

JONES, G. R. Life history methodology. In: MORGAN, G. (Ed.). Beyond method: strategies for social research. Beverly Hills: Sage, 1983. p. 147-159.

KAPLAN, C. Resisting autobiography: out-law genres and transnational feminist subjects. In: SMITH, S.; WATSON, J. De/Colonizing the subject: the politics of gender in women's autobiography. Minneapolis: University of Minnesota Press, 1992. p. 115-138.

KAPLAN, C. Autobiografia de resistência: gêneros fora-da-lei e sujeitos feministas transnacionais. Travessia, n. 29/30, p. 63-100, 1997.

LANGELLIER, K. M. Personal narratives: perspectives on theory and research. Text and Performance Quarterly, v. 9, n. 4, p. 242-276, 1989.

LEWIS, O. The children of Sanchez: autobiography of a Mexican family. New York: Random House, 1961.

PASSERINI, L. Women's personal narratives. In: PERSONAL NARRATIVES GROUP (Ed.). Interpreting women's lives: feminist theory and personal narratives. Bloomington: Indiana University Press, 1989. p. 198-198.

PERSONAL NARRATIVES GROUP. Introduction. In: PERSONAL NARRATIVES GROUP (Ed.). Interpreting women's lives: feminist theory and personal narratives. Bloomington: Indiana University Press, 1989. p. 3-15. 
PORTELLI, A. The peculiarities of oral history. History Workshop Journal, n. 12, p. 96-107, 1981.

QUEIROZ, M. I. P. Relatos orais: do “indizível” ao “dizível”. In: VON SIMSON, O. de M. (Ed.). Experimentos com histórias de vida. São Paulo: Edições Vértice, 1988. p. 14-43.

RABINOW, P.; SULLIVAN, W. M. (Ed.). Interpretive social science: a reader. Berkeley: University of California Press, 1979.

RICOEUR, P. The model of the text: meaningful action considered as a text. In: RABINOW, P.; SULLIVAN, W. M. (Ed.). Interpretive social science: a reader. Berkeley: University of California Press, 1979. p. 73-101.

ROSALDO, R. Doing oral history. Social Analysis, n. 9, p. 18-26, 1980.

ROSALDO, R. Culture and truth: the remaking of social analysis. Boston: Beacon Press, 1989.

SAID, E. The world, the text, and the critic. Cambridge: Harvard University Press, 1983.

SALAZAR, C. A Third World woman's text: between the politics of criticism and cultural politics. In: GLUCK, S. B.; PATAI, D. (Ed.). Women's words: the feminist practice of oral history. New York: Routledge, 1991. p. 93-106.

SOMMER, D. No secrets: Rigoberta’s guarded truth. Women's Studies, n. 20, p. 51-72, 1991.

TAYLOR, C. Philosophy and the Human Sciences: philosophical papers. Cambridge: Cambridge University Press, 1985.

WATSON, L. C.; WATSON-FRANKE, M. B. Interpreting life histories: an anthropological approach. New Brunswick, NJ: Rutgers University Press, 1985.

YÚDICE, G. Testimonio and Postmodernism. In: GUGELBERGER, G. M. (Ed.). The real thing: testimonial discourse in Latin America. Durham: Duke University Press, 1996. p. 42-57. 